\title{
PEMANFAATAN LIMBAH CAIR INDUSTRI TAHU UNTUK PRODUKSI BIOMASSA MIKROALGA Nannochloropsis $S p$ SEBAGAI BAHAN BAKU BIODIESEL
}

\author{
Widayat $^{*)}$ dan Hadiyanto \\ Jurusan Teknik Kimia, Fakultas Teknik Universitas Diponegoro \\ Jl. Prof. Sudharto, SH, Tembalang, Semarang 50275, Tep/Fax. (024)7460058 \\ ${ }^{*}$ Penulis korespondensi : yayat_99@yahoo.com
}

\begin{abstract}
UTILIZATION OF TOFU INDUSTRY WASTE FOR MICROALGAE Nannochloropsis $s p$ BIOMASS AS BIODIESEL FEED STOCK. Indonesia is one of productive tofu producer both for industry or home made scale. Tofu industries contribute wastewater up to 20 millions cubic meter $\left(\mathrm{m}^{3}\right)$ per year. Currently, tofu waste water was treated by anaerobic and aerobic methods which reveal some disadvantages. To overcome the disadvantages of both methods, wastewater of tofu industry was used as a medium for the cultivation of microalgae.Nannochloropsis sp is one of microalgae species which has high content of lipid and thus can be converted to biodiesel. This study examined the growth rate, biomass productivity, reduced organic levels of COD and BOD, and total lipid of microalgae Nannochloropsis sp which cultivated in tofu wastewater medium. The optimum growth of Nannochloropsis sp was found at $20 \%$ vol of liquid wastewater which produce lipids of $34.25 \%$ and also can reduce $\mathrm{COD}$ up to $77.40 \%$. The optimum nutrients of $\mathrm{NaHCO}_{3}$ was showed at the composition of $70 \mathrm{mg} / \mathrm{L}$ which decrease COD up to $78.81 \%$ and produce lipids $16.841 \%$. The addition of nutrition every 4 days was able to reduce the COD up to $81.835 \%$ and produce $14.195 \%$ yield of lipids.
\end{abstract}

Keywords: biodiesel; COD \& BOD; Nannochloropsis sp; tofu wastewater

\begin{abstract}
Abstrak
Indonesia merupakan salah satu negara penghasil tahu yang cukup produktif baik skala industri maupun rumahan.Industri tahu menyumbang limbah cair mencapai 20 juta meter kubik $\left(\mathrm{m}^{3}\right)$ per tahun. Pada saat ini pengolahan limbah tahu cair dilakukan dengan metode anaerobik maupun aerobik. Akan tetapi kedua metode tersebut memiliki beberapa kelemahan. Untuk mengatasi kelemahan kedua metode tersebut, limbah tahu cair dapat dimanfaatkan sebagai media kultivasi mikroalga. Nannochloropsis sp merupakan mikroalga yang mampu menghasilkan lipid yang besar tersebut dapat dikonversi menjadi salah satu energi alternatif biodiesel. Dalam penelitian ini dikaji laju pertumbuhan, produktivitas biomassa, penurunan kadar organik COD dan BOD, dan total lipid mikroalga jenis Nannochloropsis sp yang dikultivasi pada medium limbah tahu cair. Pertumbuhan Nannochloropsis sp. optimum pada medium $20 \%$ volume limbah tahu cair yang menghasilkan lipid sebanyak 34,25\% dan dapat menurunkan COD hingga 77,40\%. Penambahan nutrisi $\mathrm{NaHCO}_{3}$ optimum pada komposisi $70 \mathrm{mg} / \mathrm{l}$ yang mampu menurunkan COD sebesar 78,81\% dan menghasilkan lipid sebanyak 16,841\%. Waktu penambahan nutrisi setiap 4 hari sekali mampu menurunkan COD sebesar $81,835 \%$ dan menghasilkan lipid sebesar 14,195\%.
\end{abstract}

Kata kunci: biodiesel; $C O D \&$ BOD; Nannochloropsis sp; limbah tahu

How to Cite This Article: Widayat dan Hadiyanto, (2015), Pemanfaatan Limbah Cair Industri Tahu untuk Produksi Biomassa Mikroalga Nannochloropsis Sp sebagai Bahan Baku Biodiesel, Reaktor, 15(4), 253-260, http://dx.doi.org/ 10.14710/reaktor.15.4.253-260

\section{PENDAHULUAN}

Indonesia merupakan salah satu negara penghasil tahu yang cukup produktif baik skala industri maupun rumahan dengan jumlah industri mencapai 84 ribu unit usaha dengan kapasitas produksi sekitar 2,56 juta ton per tahun. Industri tahu 
menyumbang limbah cair yang diprediksi mencapai 20 juta meter kubik $\left(\mathrm{m}^{3}\right)$ per tahun. Jumlah limbah cair tahu dari $1 \mathrm{~kg}$ kedelai setiap proses adalah ratarata sebesar 43,5 liter dengan kandungan protein, lemak, karbohidrat, vitamin, asam organik, asam amino, isoflavon, saponin, $\mathrm{P}, \mathrm{Ca}, \mathrm{Fe}$ dan nutrien lain (Nurhasan dan Pramudyanto, 1987; Barbosa dkk., 2006; Tang dan Ma, 2009). Nutrien-nutrien tersebut sangat berguna dalam proses kultivasi untuk produksi mikroalga.

Pada saat ini pengolahan limbah tahu cair dilakukan dengan metode anaerobik maupun aerobik. Akan tetapi kedua metode tersebut memiliki beberapa kelemahan. Proses anaerobik memiliki kelemahan yakni tidak mampu menghilangkan kandungan nitrogen dan phosphor, serta membutuhkan penambahan basa untuk pengaturan kebasaan (Metcalf dan Eddy, 2003). Metode aerobik tidak hanya menghilangkan kandungan organik dan nutrien, tetapi juga menghasilkan $\mathrm{CO}_{2}$ dan lumpur aktif yang merupakan limbah hasil pengolahan limbah tahu (Hongyang dkk., 2011).

Untuk mengatasi permasalahan di atas, terdapat metode yang dapat ditempuh yakni memanfaatkan limbah tahu cair sebagai medium kultivasi mikroalga. Beberapa mikroalga tidak hanya mampu menghilangkan polutan, tetapi juga mampu menghasilkan lipid yang dapat dikonversi menjadi biodiesel (Perez-Garcia dkk., 2011; Bhatnagar dkk., 2010; Li dkk., 2008). Mikroalga tersebut diantaranya Chlorella pyrenoidosa, Scenedesmus obliquus, Chlorella minutissima, dan Spirulina platensis (Hongyang dkk., 2011; Martínez dkk., 2000; Bhatnagar dkk., 2010; Yang dkk., 2008). Mikroalga di atas mampu dan efektif dalam menghilangkan polutan dalam suatu limbah, tetapi memiliki produktivitas dan kandungan lipid yang rendah serta tidak toleran tehadap lingkungan yang ekstrim (Hongyang dkk., 2011; Chisti, 2008).

Pemilihan mikroalga yang akan dikultivasi sangat bergantung pada kemampuan menghilangkan polutan, produktivitas lipid dan kemudahan beradaptasi dengan lingkungan. Nannochloropsis $s p$ merupakan mikroalga yang mampu menghasilkan lipid hingga $\pm 68 \%$ (basis kering) serta toleran dengan kondisi lingkungan (Chisti, 2008). Kadar lipid yang besar tersebut dapat dikonversi menjadi salah satu energi alternatif biodiesel. Biodiesel merupakan salah satu bahan bakar alternatif yang potensial untuk mensuplai bahkan menggantikan minyak solar karena memiliki karaktersitik yang mirip (Hambali dkk., 2006).

Sistem kultivasi mikroalga membutuhkan medium yang memiliki kandungan cukup nutrisi untuk pertumbuhannya. Limbah cair tahu mengandung nutrisi yang masih berguna dan tidak mengandung zat beracun dan berbahaya, sehingga limbah tahu dapat jadikan sebagai medium kultivasi. Karena pentingnya kultivasi, maka dilakukan penelitian untuk mengkaji laju pertumbuhan, produktivitas biomassa, penurunan kadar organik COD dan BOD, dan total lipid mikroalga jenis Nannochloropsis sp yang dikultivasi pada medium limbah tahu cair.

\section{METODE PENELITIAN \\ Bahan dan Alat}

Limbah cair industri tahu diperoleh dari UKM di Kabupaten Semarang, air laut diperoleh dari pantai Marina Semarang, mikroalga Nannochlropsis sp diperoleh dari Balai Penelitian dan Pengembangan Air Tawar Jepara, serta bahan-bahan kimia lain diperoleh dari took kimia Indrasari Semarang.

Pada penelitian ini digunakan reaktor buble column untuk kultivasi mikroalga (Gambar 1). Reaktor di lengkapi dengan lampu 12 Watt selama 24 jam secara kontinyu. Areator digunakan untuk menghasilkan $\mathrm{O}_{2}$ bagi mikroalga sekaligus digunakan untuk pengadukan. Setiap hari, optical density dari mikroalga diukur untuk mengetahui konsentrasi dan pertumbuhan sel mikroalga.

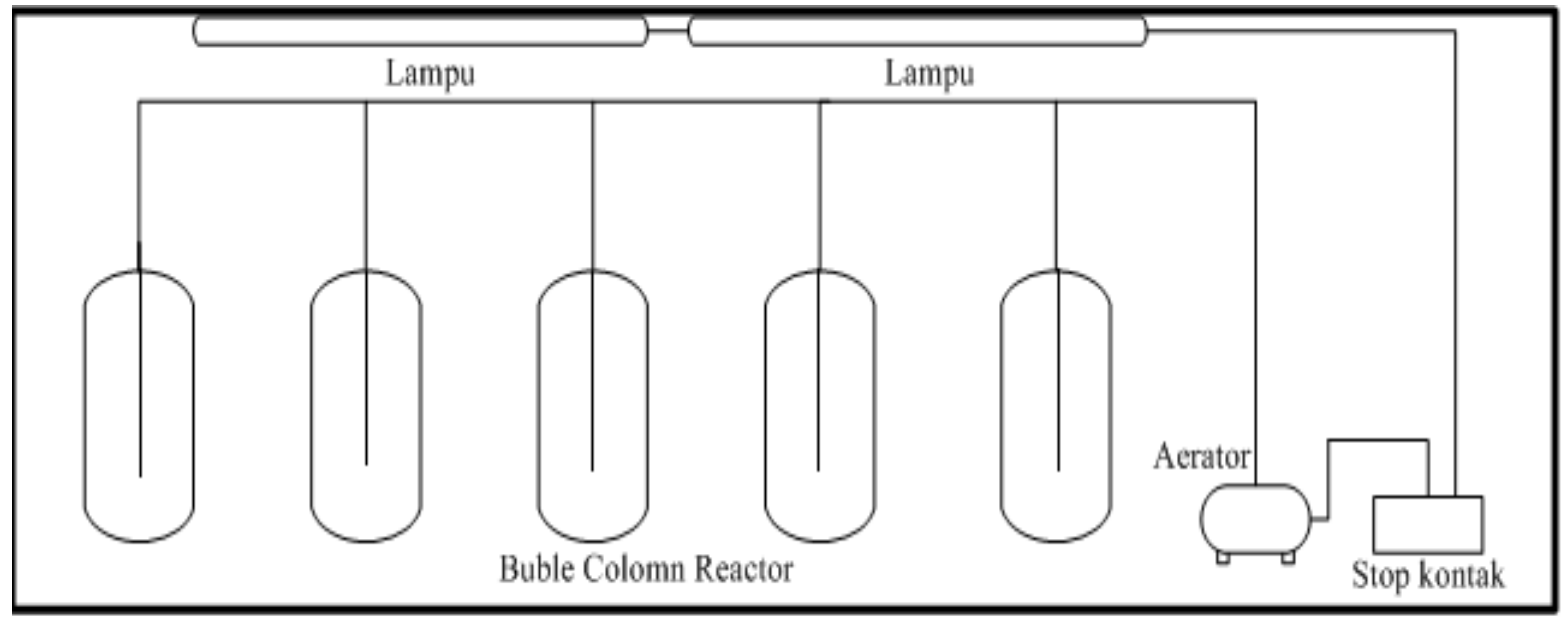

Gambar 1. Rangkaian peralatan kultivasi mikroalga dalam photobioreaktor bubble column 
Pada penelitian ini digunakan variabel penelitian \%vol limbah tahu dalam medium (0-100\% vol) yang diset pada ukuran $3 \mathrm{~L}$. Komposisi $\mathrm{NaHCO}_{3}$ yang ditambahkan ke dalam medium (0-70 mg/L) dan waktu penambahan nutrien yang dilakukan pada awal kultivasi sampai 6 hari penambahan nutrisi. Perbedaan perlakuan tanpa nutrisi juga dilakukan untuk membandingkan kecepatan pertumbuhannya. Volume kultur mikroalga dibuat tetap pada $10 \%$ vol, sedangkan temperatur dan $\mathrm{pH}$ dijaga tetap pada 25$30^{\circ} \mathrm{C}$ dan $\mathrm{pH}$ 7-9. Pupuk urea, NPK ditambahkan sebesar 30 ppm ke dalam medium sebagai nutrisi awal dari mikroalga.

\section{Prosedur Kultivasi Mikroalga}

Pengambilan limbah tahu cair dari daerah sentra produksi tahu di daerah Kelurahan Mrican, Kecamatan Lamper Tengah, Semarang. Limbah tahu cair tersebut difiltrasi untuk mengurangi jumlah total padatan. Bahan baku yang meliputi air laut dan limbah tahu cair disterilisasi dengan cara dididihkan menggunakan tungku pemanas.

Limbah tahu cair dan air laut sesuai variabel komposisi (0\%; 20\%; 40\%; 60\%, 80\%, 100\%) dicampurkan kemudian dimasukan ke dalam bak kultivasi ukuran $3000 \mathrm{ml}$. Nutrien NPK, TSP, dan Ureasebanyak $30 \mathrm{mg} / \mathrm{l}$ dan nutrien $\mathrm{NaHCO}_{3}$ sebagai sumber karbonat di tambahkan sesuai variabel dilanjutkan dengan pengadukan untuk tujuan homogenisasi.

\section{Analisis Hasil}

Analisa yang dilakukan dalam penelitian ini meliputi Optical Density (OD), perhitungan jumlah sel, biomassa, Chemical Oxygen Demand (COD) dan kadar lipid yang terkandung dalam mikroalga. Optical density diukur dengan alat spektrofotometer sinar tampak pada panjang gelombang $680 \mathrm{~nm}$. Jumlah sel diukur dengan menggunakan alat hemocytometer Adapun konsentrasi biomassa diukur dengan menggunakan spektrofotometer sinar tampak pada panjang gelombang $680 \mathrm{~nm}$. Kurva kalibrasi hubungan antara konsentrasi biomassa dengan optical density, serta hubungan antara jumlah sel dengan optical density. Konsentrasi biomassa dilakukan pada 7,21-11,46 (gr/ml) dan jumlah sel pada nilai (21134) $\times 10^{6}$. Nilai jumlah sel diperoleh dengan pengukuran dengan alat hemocytometer pada konsentrasi biomassa 7,21-11,46 (gr/ml) (Hadiyanto dkk., 2012). Konsentrasi COD diukur dengan metode permanganometri dan konsentrasi minyak diukur dengan metode ekstrasi dengan soxhlet.

\section{HASIL DAN PEMBAHASAN}

Pengaruh Konsentrasi Limbah Tahu terhadap Optical Density, Jumlah Sel, Biomassa, COD, dan Lipid

Gambar 2 menunjukkan bahwa dengan penambahan $20 \%$ volume limbah tahu cair, laju pertumbuhan Nannochloropsis sp. paling baik dibandingkan yang lainnya. Sedangkan penambahan $20 \%$ limbah tahu cair memerlukan tahap pre-culture sehingga nilai optical density selama 10 hari massa kultivasi cenderung naik pada awal kultivasi, kemudian menurun pada pertengahan kultivasi dan akan mengalami peningkatan di akhir kultivasi. Peningkatan optical density pada awal kultivasi adalah efek dari proses homogenisasi antara air laut dengan total padatan tersuspensi dalam limbah tahu cair. Sedangkan penurunan optical density pada pertengahan kultivasi diakibatkan oleh adanya senyawa kimia yang mengalami degradasi menjadi senyawa yang lebih sederhana.

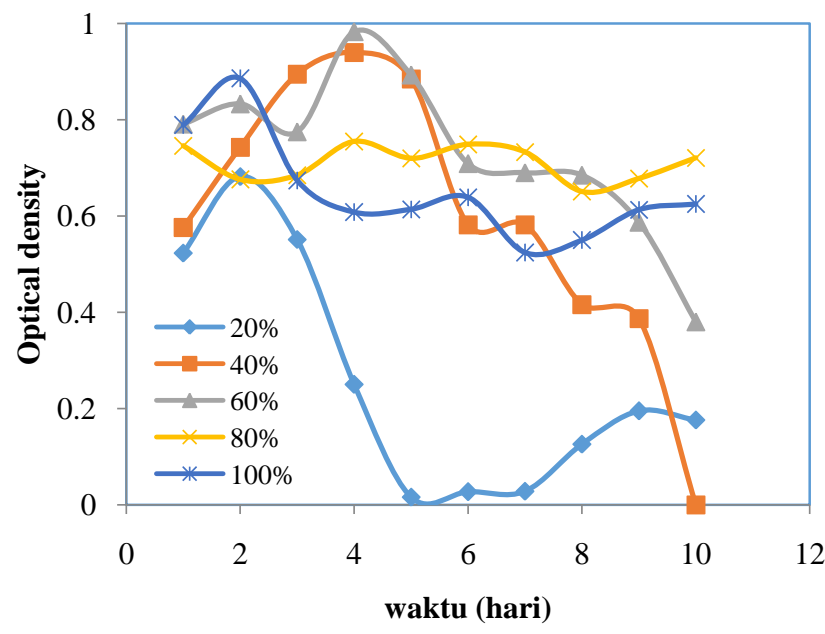

Gambar 2. Hubungan antara Optical Density dengan waktu kultivasi

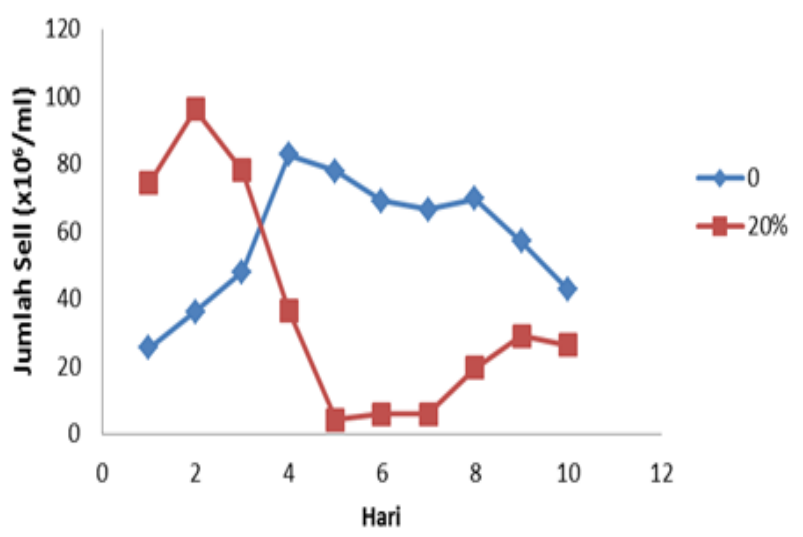

Gambar 3. Hubungan antara jumlah sel dengan waktu kultivasi

Gambar 3 menunjukkan bahwa untuk variabel $20 \% \mathrm{~V}$ dengan semakin lamanya masa kultivasi maka jumlah sel juga semakin meningkat, begitu pula untuk variabel $0 \% \mathrm{~V}$. Hal tersebut dikarenakan mikroalga Nannochloropsis sp. mengalami pertumbuhan setiap harinya dengan cara pembelahan sel, sehingga jumlah sel meningkat setiap harinya. Pada fase eksponensial pembelahan sel paling aktif sehingga jumlah sel yang dihasilkan lebih banyak (Chalid dkk., 2007). Kultivasi Nannochloropsis sp. menggunakan air laut menghasilkan jumlah sel yang lebih banyak 
dibandingkan dengan menggunakan limbah tahu cair $20 \%$ pada 10 hari massa kultivasi. Hal tersebut dikarenakan pada medium air laut, Nannochloropsis $s p$. tidak perlu melakukan tahap pre-culture karena medium air laut sudah sesuai kondisinya, baik $\mathrm{pH}$ maupun salinitas, tetapi untuk medium kultivasi $20 \% \mathrm{~V}$, dengan bertambahnya massa kultivasi, jumlah sel yang dihasilkan menjadi lebih banyak dibandingkan dengan air laut karena ketersediaan nutrisi dalam limbah tahu yang lebih tercukupi.

Pengukuran biomasa untuk 0 dan 20\% ditunjukkan pada Gambar 4. Hal tersebut dikarenakan jumlah sel yang dihasilkan dalam suatu medium kultivasi meningkat sehingga biomassa yang dihasilkan pun meningkat. Kultivasi Nannochloropsis sp. menggunakan medium air laut menghasilkan biomassa yang lebih baik dibandingkan dengan medium 20\% limbah tahu cair. Hal tersebut dikarenakan Nannochloropsis sp. tumbuh baik pada kondisi pH antara 7-9 dan salinitas 25-35\% (Sylvester, dkk., 2002). Air laut yang digunakan sebagai medium kultivasi sudah memiliki kondisi yang sesuai untuk pertumbuhan mikroalga, sehingga mikroalga Nannochloropsis sp. tidak melakukan tahap preculture. Sebaliknya pada medium $20 \%$ limbah tahu, Nannochloropsis sp. melakukan pre-culture terlebih dahulu sehingga pertumbuhannya lebih lambat dibandingkan medium air laut.

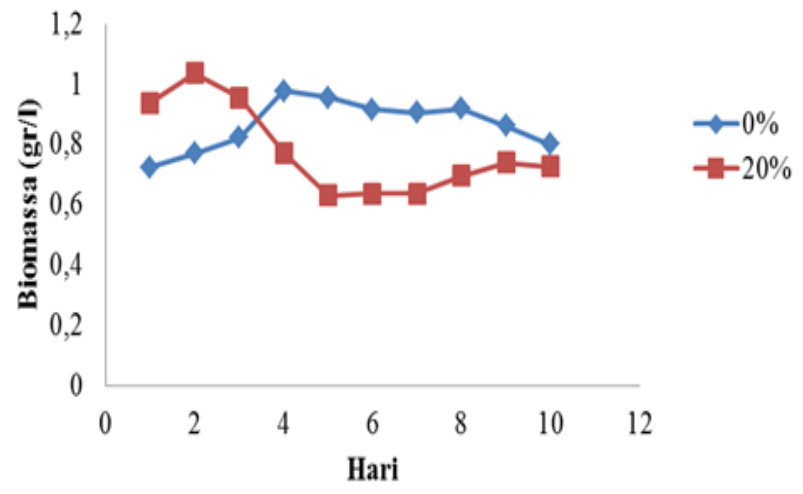

Gambar 4. Hubungan antara biomassa dengan waktu kultivasi

Pengolahan limbah tahu cair menggunakan mikroalga memberikan hasil yang cukup baik. Hal ini dapat dilihat berdasarkan Tabel 1 bahwa penggunaan mikroalga jenis Nannochloropsis sp. dapat menurunkan COD hingga 82,35\%. Apabila dibandingkan dengan penelitian sebelumnya oleh Hongyang dkk. (2011), penggunaan mikroalga jenis Nannochloropsis sp. memiliki kemampuan dalam pengolahan limbah lebih baik. Penurunan COD terbaik terjadi pada variabel $60 \%$ dimana penurunannya mecapai $82,35 \%$, sedangkan variabel $20 \%$ hanya mampu menurunkan COD hingga $77,40 \%$. Variabel $60 \%$ mengandung kadar organik yan lebih besar dibandingkan $20 \%$, oleh karena itu pembelahan mikroalga menjadi lebih optimal. Kondisi optimal ini terbukti dengan adanya penurunan COD yang lebih besar.
Tabel 1. Pengaruh \% volume limbah tahu cair terhadap penurunan COD sesudah dilakukan pengolahan dengan Nannochloropsis sp.

\begin{tabular}{ccccc}
\hline & \multirow{2}{*}{$\begin{array}{c}\text { Variabel } \\
(\% \mathrm{~V})\end{array}$} & Awal & Akhir & $\begin{array}{c}\% \\
\text { No }\end{array}$ \\
\cline { 3 - 5 } & 0 & 980,645 & 960,000 & 2,11 \\
\hline 1 & 20 & 4129,032 & 933,333 & 77,40 \\
2 & 40 & 4645,161 & 960,000 & 79,40 \\
3 & 60 & 6193,548 & 1093,333 & 82,35 \\
4 & 80 & 6709,677 & 1760,000 & 73,77 \\
5 & 100 & 9333,333 & 2400,000 & 74,29 \\
6 & & & & \\
\hline
\end{tabular}

Pengolahan limbah cair tahu tidak hanya dapat menurukan COD tetapi juga mampu menghasilkan biomassa dengan kadar lipid yang lebih besar dibandingkan dengan medium asal yakni air laut. Hal ini dapat dilihat pada Tabel 2 bahwa kadar lipid pada komposisi limbah tahu cair 20\% mengandung kadar lipid 34,25\%, sedangkan pada komposisi 0\% limbah tahu biomassa hanya mengandung 32,5\%. Fenomena ini terjadi karena pada komposisi $20 \%$ ketersediaan nutrisi lebih banyak dibandingakan komposisi $0 \%$ (tanpa penambahan limbah tahu cair). Karbohidrat sebagai sumber glukosa yang sangat berperan dalam pertumbuhan dan produksi lemak mikroalga, semakin banyak ketersedian glukosa maka tingkat pertumbuhan dan kadar lemak yang dihasilkan juga semakin besar (Li dkk., 2013).

Tabel 2. Pengaruh \% volume limbah tahu cair terhadap kadar lipidmikroalga Nannochloropsis $s p$.

\begin{tabular}{ccc}
\hline No & Variabel $(\% \mathrm{~V})$ & Kadar Lipid $(\% \mathrm{wt})$ \\
\hline 1 & 0 & 32,50 \\
2 & 20 & 34,25 \\
\hline
\end{tabular}

Pengaruh Komposisi $\mathrm{NaHCO}_{3}$ terhadap Optical Density, Jumlah Sel, Biomassa, COD, dan Lipid

Gambar 5 menunjukkan bahwa untuk setiap variabel penambahan $\mathrm{NaHCO}_{3}$ pada kultivasi Nannochloropsis $s p$. mengalami pertumbuhan setiap harinya yang ditunjukkan dengan peningkatan optical density. Hal tersebut karena kepadatan sel mikroalga meningkat setiap harinya. Laju pertumbuhan Nannochloropsis sp. dapat dilihat mulai hari ke-5 setelah tahap pre-culture. Laju pertumbuhan mikroalga Nannochloropsis sp. pada variabel 5 dengan penambahan $70 \mathrm{mg} / \mathrm{NaHCO}_{3}$ paling baik dibandingkan dengan variabel yang lainnya. Hal tersebut dikarenakan semakin banyak penambahan $\mathrm{NaHCO}_{3}$ sebagai sumber karbon untuk kultivasi mikroalga Nannochloropsis sp. maka pertumbuhan Nannochloropsis sp. semakin baik (Taw, 1990). Adanya ketersediaan sumber karbon yang cukup selama massa kultivasi berdampak pada pertumbuhan Nannochloropsis sp. yang optimal. Hal tersebut diindikasikan dengan peningkatan optical density setiap harinya. 


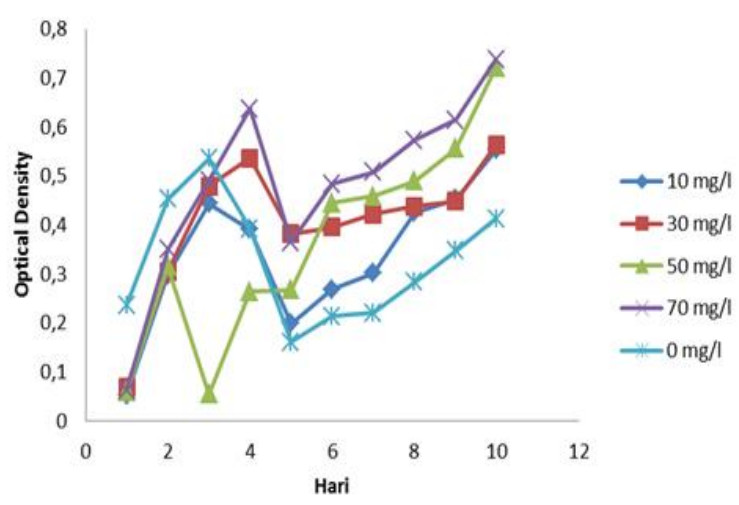

Gambar 5. Hubungan antara Optical Density dengan waktu kultivasi

Peningkatan jumlah sel paling baik terjadi pada penambahan $70 \mathrm{mg} / \mathrm{l} \mathrm{NaHCO}_{3}$. Pada variabel ini, jumlah sel mikroalga Nannochloropsis sp. mencapai $1,03 \times 10^{8} \mathrm{sel} / \mathrm{ml}$ (Gambar 6). Hal ini dikarenakan semakin banyak ketersediaan $\mathrm{NaHCO}_{3}$ dalam medium, maka pertumbuhan dan fotosintesis mikroalga Nannochloropsis sp. berjalan optimal. $\mathrm{NaHCO}_{3}$ merupakan sumber karbon yang berperan sebagai bahan baku dalam proses fotosintesis. Mikroalga akan mengalami pertumbuhan yang baik atau optimum apabila kebutuhan nutriennya terpenuhi (Sylvester dkk., 2002; Edhy dkk., 2003). Pada percobaan tanpa penambahan nutrisi, mikroalga Nannochloropsis sp. masih dapat bertahan hidup selama massa kultivasi 10 hari. Hal tersebut disebabkan nutrisi alami yang terdapat pada limbah tahu cair masih mencukupi untuk pertumbuhan Nannochloropsis sp. hingga 10 hari massa kultivasi. Namun, pertumbuhan Nannochloropsis sp. kurang optimum karena kebutuhan nutrisi untuk kultivasi Nannochloropsis $s p$. tidak terpenuhi dengan baik.

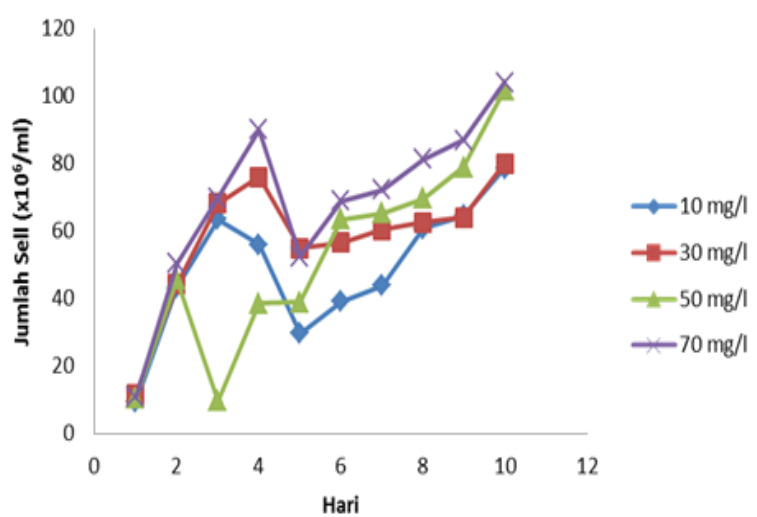

Gambar 6. Hubungan antara jumlah sel dengan waktu kultivasi

\section{Pengaruh Komposisi $\mathrm{NaHCO}_{3}$ Limbah Tahu terhadap Biomassa}

Pertumbuhan

biomassa mikroalga Nannochloropsis sp. dengan penambahan $70 \mathrm{mg} / \mathrm{l}$ $\mathrm{NaHCO}_{3}$ paling baik dibandingkan dengan variabel yang lainnya (Gambar 7). Hal ini dikarenakan semakin banyak penambahan $\mathrm{NaHCO}_{3}$ sebagai sumber karbon untuk kultivasi mikroalga Nannochloropsis sp. maka pertumbuhan Nannochloropsis sp. semakin baik sehingga biomassanya pun meningkat. Karbon berpengaruh pada proses fotosintesis dari mikroalga dengan bantuan sinar matahari sesuai dengan persamaan reaksi sbb:

$$
\mathrm{CO}_{2}+\mathrm{H}_{2} \mathrm{O}+\text { Energi [Cahaya] } \rightarrow\left(\mathrm{CH}_{2} \mathrm{O}\right) \mathrm{n}+\mathrm{O}_{2}
$$

Dari reaksi di atas dapat disimpulkan bahwa dengan bertambahnya karbon maka biomassa dalam bentuk $\left(\mathrm{CH}_{2} \mathrm{O}\right)$ n semakin meningkat. Mikroalga akan mengalami pertumbuhan yang baik atau optimum apabila kebutuhan nutriennya terpenuhi (Sylvester dkk., 2002; Edhy dkk., 2003).

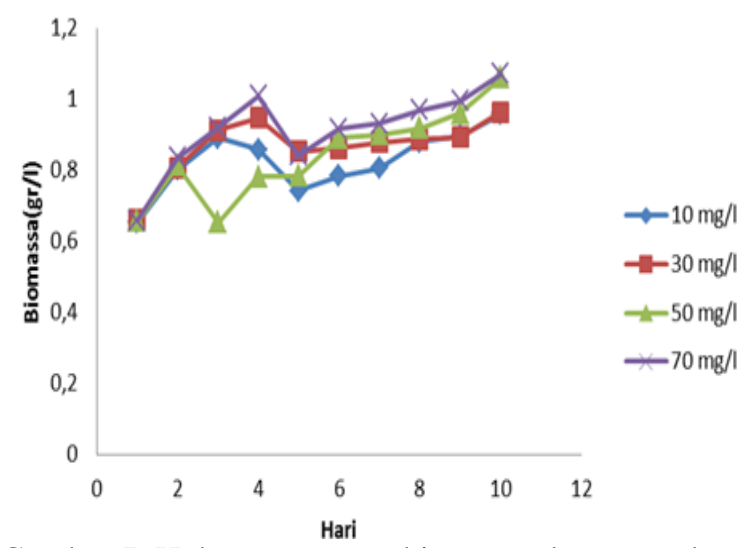

Gambar 7. Hubungan antara biomassa dengan waktu kultivasi

Tabel 3 menunjukan bahwa komposisi $\mathrm{NaHCO}_{3}$ sangat berpengaruh terhadap penurunan COD. Semakin besar komposisi $\mathrm{NaHCO}_{3}$ yang ditambahkan maka semakin besar pula penurunan COD limbah. Penurunan COD terbesar terjadi saat penambahan $\mathrm{NaHCO}_{3}$ sebesar $70 \mathrm{mg} / \mathrm{l}$. Pada variabel ini mikroalga Nannochloropsis sp. mampu menurunkan COD dari 4129,032 mg/L menjadi 875 $\mathrm{mg} / \mathrm{L}$.Hal ini dikarenakan semakin banyak ketersediaan $\mathrm{NaHCO}_{3}$ dalam medium, maka proses pertumbuhan dan fotosintesis mikroalga dapat berjalan optimal (Taw, 1990). $\mathrm{NaHCO}_{3}$ merupakan sumber karbonat yang dapat dikonversikan menjadi $\mathrm{CO}_{2}$ dan berperan sebagai bahan baku proses fotosintesis. Berikut ini reaksi fotosintesis menurut Cooney dkk. (2011)

$$
\mathrm{CO}_{2}+\mathrm{H}_{2} \mathrm{O}+\text { n photons } \longrightarrow\left(\mathrm{CH}_{2} \mathrm{O}\right) \mathrm{n}+\mathrm{O}_{2}
$$

Tabel 3. Pengaruh \% volume limbah tahu cair terhadappenurunan COD sesudah dilakukan pengolahan dengan Nannochloropsis sp.

\begin{tabular}{lllll}
\hline No & $\begin{array}{l}\text { Variabel } \\
\end{array}$ & \multicolumn{3}{c}{ COD $(\mathrm{mg} / \mathrm{l})$} \\
\cline { 3 - 5 } & Awal & Akhir & $\%$ Penurunan \\
\hline 1 & 10 & 4129,032 & 1000 & 75,78 \\
2 & 30 & 4129,032 & 925 & 77,60 \\
3 & 50 & 4129,032 & 900 & 78,20 \\
4 & 70 & 4129,032 & 875 & 78,81 \\
\hline
\end{tabular}


Ketersediaan sumber karbonat yang mencukupi, maka pertumbuhan Nannochloropsis sp. berjalan optimal. Pertumbuhan yang optimal dapat diindikasikan dengan jumlah sel yang sangat padat yakni berkisar $1,03 \times 10^{8} \mathrm{sel} / \mathrm{ml}$. Hal ini mengakibatkan konsumsi senyawa organik dari limbah tahu meningkat, dengan demikian kadar organik COD dari limbah tahu turun secara signifikan.

Tabel 4 menunjukkan bahwa kadar lipid tertinggi terjadi pada variabel $50 \mathrm{mg} / \mathrm{l}$ dengan kadar lipid sebesar $25,19 \%$. Penambahan $\mathrm{NaHCO}_{3}$ lebih dari $50 \mathrm{mg} / \mathrm{l}$ dapat menurunkan kadar lipid secara signifikan. Hal ini dapat ditunjukkan pada variabel 70 $\mathrm{mg} / \mathrm{l}$ dimana biomassa mikroalga Nannochloropsis $s p$. memiliki kadar lipid hanya 16,841\%. Fenomena ini terjadi karena penambahan $\mathrm{NaHCO}_{3}$ yang berlebihan justru menjadi inhibitor dalam proses fotosintesis.

Tabel 4. Pengaruh \% volume limbah tahu cair terhadapkadar lipidmikroalga Nannochloropsis sp.

\begin{tabular}{lll}
\hline No & Variabel (mg/l) & Kadar Lipid (\%wt) \\
\hline 1 & 10 & 21,159 \\
2 & 30 & 19,969 \\
3 & 50 & 25,190 \\
4 & 70 & 16,841 \\
\hline
\end{tabular}

Pengaruh Waktu Penambahan Nutrisi terhadap Optica Density, Jumlah Sel, Biomassa, COD, dan Lipid

Penambahan nutrien setiap 4 hari sekali optimum pada kultivasi mikroalga Nannochloropsis $s p$. Penambahan nutrien lebih dari 4 hari sekali akan berdampak mikroalga Nannochloropsis sp. kekurangan nutrien (Gambar 8).

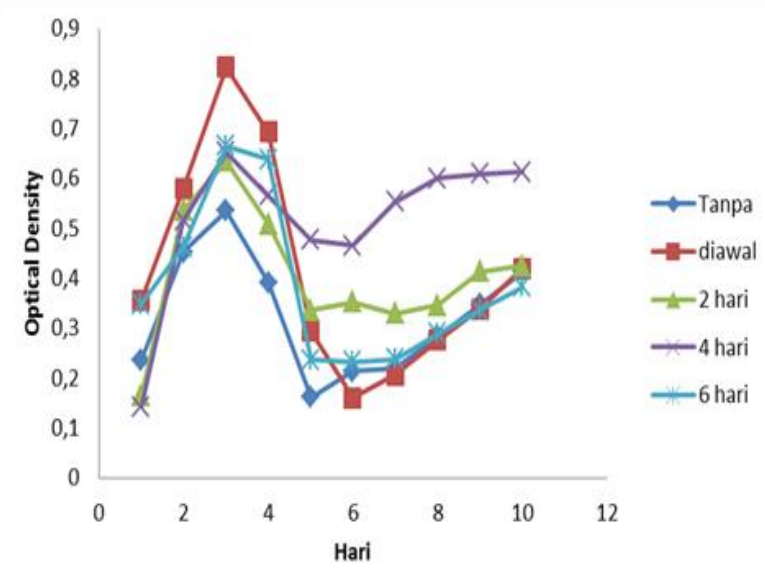

Gambar 8. Hubungan antara Optical Density dengan waktu kultivasi

Apabila asupan yang diperoleh mikroalga selama kultivasi tidak mencukupi, maka akan menghambat pertumbuhan (Hadiyanto dkk., 2012). Penambahan nutrien yang lebih cepat dari 4 hari sekali kurang optimal karena nutrisi yang terdapat dalam medium kultivasi berlebihan jumlahnya. Pada penelitian sebelumnya juga disebutkan bahwa pada media yang memiliki kandungan unsur hara yang terlalu tinggi akan menyebabkan pertumbuhan mikroalga terhambat karena mikroalga tersebut memerlukan waktu yang lebih lama untuk beradaptasi (Chilmawati dan Suminto, 2010).

Pada Gambar 9 ditunjukkan bahwa waktu penambahan nutrien yang berbeda akan menghasilkan pertumbuhan jumlah sel yang berbeda juga. Pada variabel penambahan nutrien setiap 4 hari sekali menghasilkan pertumbuhan jumlah sel yang paling baik dibandingkan yang lainnya. Hal tersebut dikarenakan mikroalga akan mengalami pertumbuhan yang baik atau optimum apabila kebutuhan nutrientnya terpenuhi (Sylvester dkk., 2002; Edhy dkk., 2003).

Penambahan nutrien lebih dari 4 hari sekali mengakibatkan pembelahan sel terhambat sehingga jumlah sel sedikit. Sedangkan penambahan nutrien yang lebih cepat dari 4 hari sekali mengakibatkan unsur hara yang terkandung berlebih sehingga pertumbuhan mikroalga terhambat karena mikroalga tersebut memerlukan waktu yang lebih lama untuk beradaptasi (Chilmawati dan Suminto, 2010).

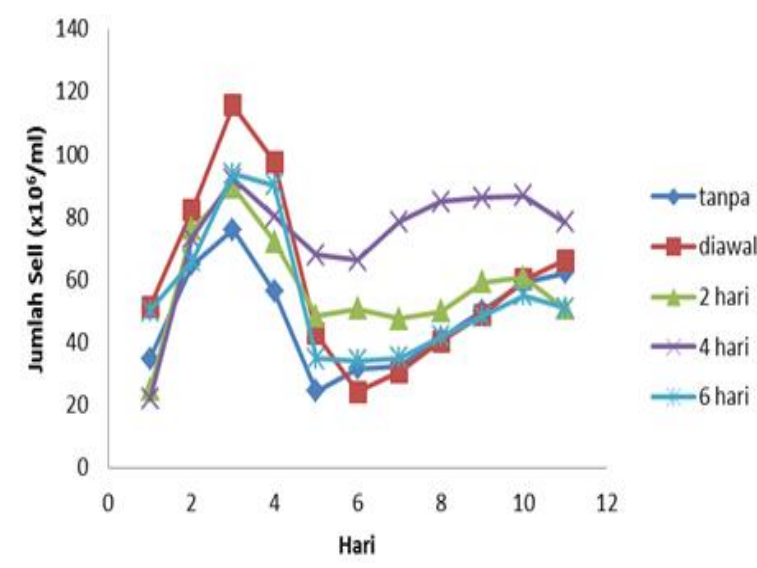

Gambar 9. Hubungan antara jumlah sel dengan waktu kultivasi

Pada penambahan nutrien lebih dari 4 hari sekali akan menghasilkan biomassa yang lebih sedikit karena kebutuhan nutrien yang tidak tercukupi dengan baik (Gambar 10). Sedangkan pada penambahan nutrien lebih cepat dari 4 hari sekali, pertumbuhan biomassa kurang optimal karena nutrisi yang terdapat dalam medium kultivasi berlebihan jumlahnya. Media yang memiliki kandungan unsur hara yang terlalu tinggi akan menyebabkan pertumbuhan mikroalga terhambat karena mikroalga tersebut memerlukan waktu yang lebih lama untuk beradaptasi (Chilmawati dan Suminto, 2010).

Tabel 5 diketahui bahwa waktu penambahan nutrien berpengaruh pada tingkat penurunan COD limbah oleh mikroalga Nannochloropsis sp. Penurunan COD terbesar terjadi pada variabel waktu penambahan 4 hari sekali dengan penurunan sebesar $83,652 \%$. 


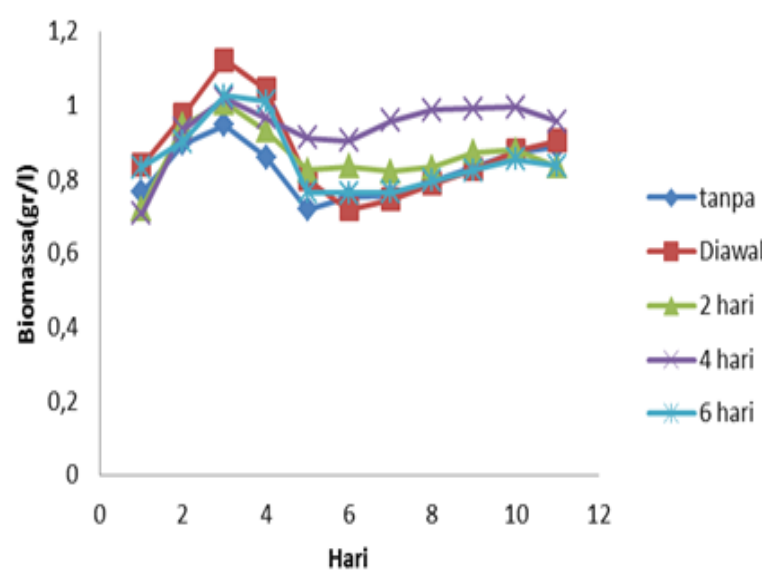

Gambar 10. Hubungan antara biomassa dengan waktu kultivasi

Tabel 5. Pengaruh \% volume limbah tahu cair terhadap penurunan COD sesudah dilakukan pengolahan dengan Nannochloropsis sp.

\begin{tabular}{ccccc}
\hline \multirow{2}{*}{ No } & Variabel & \multicolumn{3}{c}{ COD (mg/L) } \\
\cline { 3 - 5 } & (hari) & Awal & Akhir & $\%$ Penurunan \\
\hline 1 & Tanpa & 4129,032 & 750 & 81,835 \\
2 & 0 & 4129,032 & 725 & 82,441 \\
3 & 2 & 4129,032 & 700 & 83,046 \\
4 & 4 & 4129,032 & 675 & 83,652 \\
5 & 6 & 4129,032 & 750 & 81,835 \\
\hline
\end{tabular}

Kandungan nutrisi pada limbah tahu yang cukup tinggi maka penambahan nutrien lebih optimal terjadi setiap 4 hari sekali. Waktu penambahan nutrien yang lebih cepat dari 4 hari akan berdampak pada menumpuknya nutrisi pada medium sehingga justru menjadi penghambat dalam pertumbuhan mikroalga. Pada waktu penambahan nutrien lebih dari 4 hari sekali akan menyebabkan mikroalga kekurangan nutrisi sehingga pertumbuhan menjadi lambat. Pertumbuhan mikroalga yang optimal diindikasikan dengan penurunan COD yang lebih besar. Hal ini sebagai bukti adanya proses penguraian dan pemanfaatan senyawa organik oleh mikroalga untuk pertumbuhan.

Tabel 6 menunjukkan bahwa kadar lipid tertinggi terjadi pada variabel waktu penambahan di awal kultivasi di ikuti penambahan tiap 2 hari. Waktu penambahan nutrisi yang lebih dari 2 hari dapat menurunkan kadar lipid secara signifikan. Hal ini dapat ditunjukkan pada variabel 4 hari sekali dimana biomassa mikroalga Nannochloropsis sp. memiliki kadar lipid hanya $14,195 \%$. Nutrisi yang ditambahkan bertujuan untuk mempercepat proses fotosintesis untuk produksi biomassa.

Hasil penelitian yang dilakukan oleh Jiang dkk. (2011) menunjukkan bahwa produksi biomassa berbanding terbalik dengan kadar lipid berlaku pada fenomena ini. Pada variabel waktu penambahan 4 hari produksi biomassa adalah paling baik yaitu mencapai $0,95672 \mathrm{~g} / \mathrm{L}$ tetapi kadar lipidnya paling rendah yaitu $14,195 \%$. Sedangkan pada variabel 2 hari sekali yang memiliki kadar lipid tinggi mecapai $18,556 \%$ hannya memiliki berat biomassa lebih rendah yaitu 0,83472 $\mathrm{g} / \mathrm{L}$.

Tabel 6. Pengaruh \% volume limbah tahu cair terhadap kadar lipid Mikroalga Nannochloropsis sp.

\begin{tabular}{ccc}
\hline No & Variabel (hari) & Kadar Lipid (\%wt) \\
\hline 1 & Tanpa & 17,793 \\
2 & 0 & 18,818 \\
3 & 2 & 18,556 \\
4 & 4 & 14,195 \\
5 & 6 & 16,320 \\
\hline
\end{tabular}

\section{KESIMPULAN}

Pemanfaatan limbah industri tahu telah berhasil dilakukan untuk kultivasi mikroalga jenis Nannochloropsis sp dan dapat menghasilkan biomassa untuk bahan bakau industri biodiesel. Kondisi kultivasi diperoleh untuk pertumbuhan Nannochloropsis sp. optimum pada medium $20 \%$ volume limbah tahu cair dimana menghasilkan lipid sebanyak 34,25\% dan dapat menurunkan COD hingga $77,40 \%$. Penambahan nutrisi $\mathrm{NaHCO}_{3}$ optimum pada komposisi $70 \mathrm{mg} / \mathrm{l}$ yang mampu menurunkan COD sebesar 78,81\% dan menghasilkan lipid sebanyak $16,841 \%$. Waktu penambahan nutrisi setiap 4 hari sekali mampu menurunkan COD sebesar $81,835 \%$ dan menghasilkan lipid sebesar 14,195\%.

\section{UCAPAN TERIMAKASIH}

Ucapan terima kasih disampaikan kepada Laboratorium Pelayanan Terpadu (C-Biore) dan Teknik Kimia UNDIP atas kontribusinya sebagai tempat dilakukannya penelitian ini.

\section{DAFTAR PUSTAKA}

Barbosa, A.C.L., Lajolo, F.M., and Genovese, M.I., (2006), Influence of temperature, $\mathrm{pH}$ and ionic strength on the production of isoflavone-rich soy protein isolates, Food Chem, 98, pp. 757-766.

Bhatnagar, A., Bhatnagar, M., Chinnasamy, S., and Das, K., (2010), Chlorella minutissima - a promising fuel alga for cultivation in municipal wastewaters, Appl.Biochem.Biotechnol, 161, pp. 523-536.

Chalid, S.Y., Amini, S., dan Lestari, S.D.,(2007), Kultivasi Chlorella sp pada media tumbuh yang diperkaya dengan pupuk anorganik dan soil extract, Program Studi Kimia, Fakultas Sains dan Teknologi UIN Syarif Hidayatullah Jakarta.

Chilmawati, D. dan Suminto, (2010), Penggunaan media kultur yang berbeda terhadap pertumbuhan Chlorella Sp., Jurnal Saintek Perikanan, 6(1), pp. 7178.

Chisti, Y., (2008), Biodiesel from microalgae beats bioethanol, Trends in Biotechnology, 26(3), pp. 126131. 
Cooney, M.J., Young, G., and Pate, R., (2011), Bio-oil from photosynthetic microalgae: Case study, Bioresource Technology, 102, pp. 166-177.

Edhy, W.A., Januar, dan Kurniawan, (2003), Plankton di Lingkungan PT. Central Pertiwi Bahari, Laboratorium Central Department, Aquaculture Division PT. Central Pertwi Bahari. Tulang Bawang.

Hadiyanto, Widayat and Kumoro, A.C., (2012), Potency of microalgae as biodiesel source in Indonesia, Int. Journal of Renewable Energy Development, 1, pp. 23-27

Hambali, E., Suryani, A., Dadang, Hariyadi, H. Hanafie, I.K., Reksowardojo, Rivai, M., Ihsanur, M., Suryadarma, P., Tjitrosemito, S., Soerawidjaya, T.H. Prawitasari, T., Prakoso, T., dan Purnama, W., (2006), Jarak pagar-tanaman penghasil biodiesel, Seri Agribisnis, Penebar Swadaya, Jakarta:46-72

Hongyang, S., Yalei, Z., Chunmin., Z., Xuefei, Z., and Jinpeng, L., (2011), Cultivation of Chlorella pyrenoidosa in soybean processing wastewater, Bioresource Technology, 102, pp. 9884-9890.

Jiang, L., Luo., S., Fan, X., Yang, Z., and Guo, R., (2011), Biomass and lipid production of marine microalgae using municipal wastewater and high concentration of $\mathrm{CO}_{2}$, Applied Energy, 88, pp. 33363341 .

Li, Y., Horsman, M., Wu, N., Lan, C.Q., and DuboisCalero, N., (2008), Biofuels from microalgae, Biotechnol. Progr, 24, pp. 815-820.

Martínez, M.E., Sánchez, S., Jiménez, J.M., El Yousfi, F., and Mu noz, L., (2000), Nitrogen and phosphorus removal from urban wastewater by the microalga Scenedesmus obliquus, Bioresour. Technol., 73, pp. 263-272.

Nurhasan dan Pramudyanto, B.B., (1991), Penanganan Air Limbah Tahu, yayasan Bina Karya, Jakarta Selatan, http:www.menlh.go.id (24 september 2008)

Metcalf, E. and Eddy, H., (2003), Wastewater Engineering: Treatment and Reuse, McGraw Hill, New York.

Perez-Garcia, O., Escalante, F.M.E., de-Bashan, L.E., and Bashan, Y., (2011), Heterotrophic cultures of microalgae: metabolism and potential products, Water Res. 45, pp. 11-36.

Sylvester, B., Nelvy, dan Sudjiharno, (2002), Biologi fitoplankton, budidaya fitoplankton dan zooplankton, Balai Budidaya Laut Lampung, Makara Teknologi, 9, pp. 3-23.

Tang, C.-H. and Ma, C.-Y., (2009), Effect of high pressure treatment on aggregation and structural properties of soy protein isolate, LWT - Food Sci. Technol, 42, pp. 606-611.

Taw, N., (1990), Petunjuk pemeliharaan kultur murni dan massal mikroalga. proyek pengembangan udang, United nations development Programme, Food and Agriculture Organizations of the United Nations.

Yang, C.F., Ding, Z.Y., and Zhang, K.C., (2008) Growth of Chlorella pyrenoidosa in wastewater from cassava ethanol fermentation, World J. Microbiol. Biotechnol, 24, pp. 2919-2925. 